\title{
MODEL SISTEM OTOMATIS WATER TREATMENT PLANT MENGGUNAKAN PLC BERBASIS WIRELESS
}

\author{
Rendi Priyatna ${ }^{1}$, Firmansyah M S Nursuwars ${ }^{2}$, Asep Andang ${ }^{3}$ \\ Teknik Elektro, Fakultas Teknik, Universitas Siliwangi, Tasikmalaya, Indonesia ${ }^{13}$ \\ Informatika, Fakultas Teknik, Universitas Siliwangi, Tasikmalaya, Indonesia ${ }^{2}$ \\ email: 167002063@student.unsil.ac.id ${ }^{1}$
}

\begin{abstract}
Conventional water treatment process such as intake, coagulation, flocculation, sedimentation, filtration, disinfection and reservoir are carried out manually starting from turning on the intake pump, backwash process, and monitoring other instruments in the water treatment process. However, Human errors often occur which result in accidents such as leakage of distribution pipes, mismatches of production data with distribution etc. The solution to this problem is that each process is installed with sensors to find out the condition of the process then the data from the sensors installed in the plant are processed by the PLC, so that the water treatment process can be carried out automatically, then the process data is transmitted to the server using wireless to be processed and become an information that is displayed in the HMI. From the results of this study, it was found that the design of the automatic water treatment plant system model in handling the scheduling of pump intake, distribution, and backwash firing as well as well-filled data reports with data accuracy reaching $91.82 \%$ to $100 \%$ in wireless range $<80$ meters without obstruction. This can minimize errors due to human errors committed by operators and assist the reporting system for companies engaged in water treatment plant.
\end{abstract}

Keywords: HMI, PLC, Water Treatment Plant, Wireless.

\section{Abstrak}

Dalam proses pengolahan air secara konvensional seperti intake, koagulasi, flokulasi, sedimentasi, filtrasi, desinfeksi dan reservoir dilakukan secara manual mulai dari menyalakan pump intake, proses backwash, dan pemantauan alat instrument lainnya yang ada pada proses pengolahan air. Namun seringkali terjadi human error yang mengakibatkan kecelakaan seperti kebocoran pipa distribusi, ketidaksesuaian data produksi dengan distribusi dll. Untuk menangani masalah tersebut setiap proses dipasang sensor untuk mengetahui kondisi proses tersebut kemudian data-data dari sensor yang terpasang pada plant diolah oleh PLC sehingga proses pengolahan air dapat dilakukan secara otomatis, kemudian data proses tersebut di transmisikan ke server menggunakan wireless untuk diolah dan menjadi sebuah informasi yang ditampilkan dalam HMI. Dari hasil penelitian ini diperoleh bahwa rancangan model sistem otomatis water treatment plant dalam menangani hal scheduling penyalaan pump intake, distribusi, dan backwash serta report data yang terakuisi dengan baik dengan keakurasian data mencapai $91.82 \%$ sampai $100 \%$ dalam jangkauan wireless < 80 meter tanpa halangan. Hal ini dapat meminimalisir kesalahan akibat human error yang dilakukan oleh operator dan membantu sistem report pada perusahaan yang bergerak di bidang water treatment plant.

Kata Kunci: HMI, PLC, Water Treatment Plant,Wireless

\section{PENDAHULUAN}

Air merupakan sebuah kebutuhan pokok bagi kehidupan manusia, dimana air digunakan untuk minum, mandi, dan mencuci [1], menurut Kepmenkes RI No 907/MENKES/SK/VII/2002 kebutuhan air harus tercukupi berdasarkan kuantitas, kontinuitas dan kualitas yang melalui proses pengolahan memenuhi syarat kesehatan (bakteriologis, kimiawi, radioaktif, dan fisik).

Dalam proses pengolahan air terdiri dari beberapa tingkatan pengolahan yaitu intake, koagulasi, flokulasi, sedimentasi, filtrasi, dan reservoir. tetapi, dalam pengolahan secara konvensional proses tersebut dikerjakan secara manual. Mulai dari penyalaan pump intake , pump distribusi, proses backwash, dan report data pendapatan. Namun sering kali terjadinya human error yang mengakibatkan beberapa kecelakaan seperti kebocoran pada pipa distribusi akibat pressure pada pipa terlalu besar, kecurangan dalam hal membuat laporan distribusi yang mengakibatkan kerugian pada perusahaan dll.

Pada bidang otomatisasi dan kontrol yang baik sangat diperlukan dalam menangani sistem yang kompleks yang memerlukan waktu yang cepat, dan tepat yaitu dengan memanfaatkan otomatisasi berbasis PLC dengan standar dan kualitas yang sudah tidak diragukan lagi terhadap keadalan sistemnya di dunia industri [2].
Pengunaan jaringan wireless merupakan salah satu alternatif terbaik dalam membangun jaringan yang praktis dan dapat meningkatkan mobilitas pada user [3]. Maka menurut permasalahan tersebut dibuatlah model sistem otomatis water treatment plant menggunakan PLC berbasis wireless dalam jangkauan komunikasinya, dengan begitu dapat meminimalisir kesalahan human error karena sistem WTP dan report nya dikerjakan secara otomatis.

\section{KAJIAN PUSTAKA}

A. WTP (Water Treatment Plant)

Water treatment plant merupakan proses pengolahan air yang bertujuan untuk menjernihkan air hingga siap pakai. Dalam proses pengolahan air terdiri dari intake, koagulasi, flokulasi, sedimantasi, filtrasi, desinfeksi, dan reservoir [4].

\section{B. OMRON CP1L-E}

CP1L-E adalah salah satu series PLC yang dikeluarkan oleh omron yang support terhadap Modbus TCP dengan trasnmisi data melalui port ethernet [5]. Seperti yang ditunjukan pada Gbr 1. 


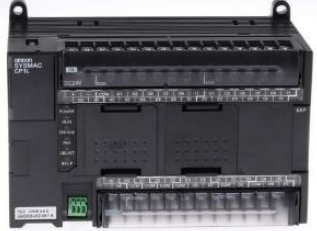

Gbr 1. OMRON CP1L-E

\section{HMI (Human Machine Interface)}

HMI merupakan sebuah sarana atau media antara machine dengan manusia dimana HMI mengumpulkan dan mengolah data dari machine menjadi informasi yang dapat dimengerti oleh manusia [6].

\section{OPC (Open Platform Communication)}

OPC adalah sebuah platform komunikasi yang dapat menerima data dari PLC, DCS, mikrokontrol, transmitertransmiter sensor, aplikasi perangkat lunak, atau lainnya. Sebab OPC dapat menerima dan mengolah base data apa yang diterimanaya. Tidak perduli dari mana data itu berasal, asalkan dasar komunikasinya apa dan seperti apa yang digunakan. Sehingga dapat di proses oleh OPC untuk dikomunikasikan dengan yang lainnya. Salah satu jenis OPC yaitu KepserverEx PTC.Inc [7]. Seperti pada Gbr 2.

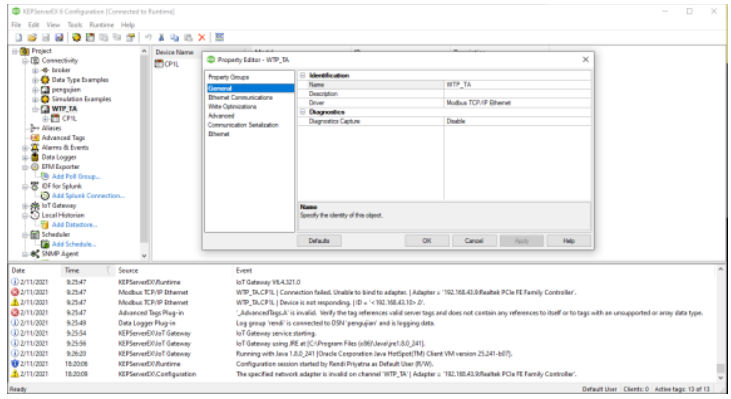

Gbr 2. Software OPC

E. Komunikasi Wireless

Komunikasi wireless merupakan sebuah jenis komunikasi tanpa kabel yaitu dengan memanfaatkan frekuensi radio dan IR untuk memberi sebuah koneksi jaringan ke seluruh dalam area sekitarnya. Area jangkauan wireless tergantung spesifikasi hardware yang digunakannya [8].

F. Demultiplekser Analog

Demultiplekser analog seperti pada Gbr 3, untuk mengatasi keteratasan jumlah kanal ADC (analog digital konverter) dari sebuah device kontrol sehingga dapat menampung lebih banyak channel analog [9].

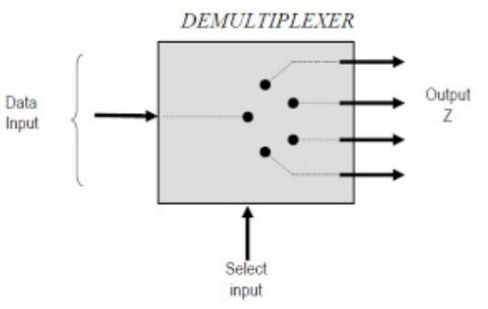

Gbr 3. Demultiplekser

\section{METODE}

Bagian ini berisi mengenai penjelasan metode yang digunakan dalam penelitian. Mulai dari perencanaan dan perancangan. Tahap perancangan terdiri dari dua bagian yaitu perancangan hardware dan software.

\section{A. Perencanaan Sistem}

Perencanaan sistem otomatis pada model Sistem WTP seperti pada Gbr 4 mengenai peletakan titik-titik sensor dan aktuator untuk tujuan pembuatan model sistem otomatis water treatment plant.

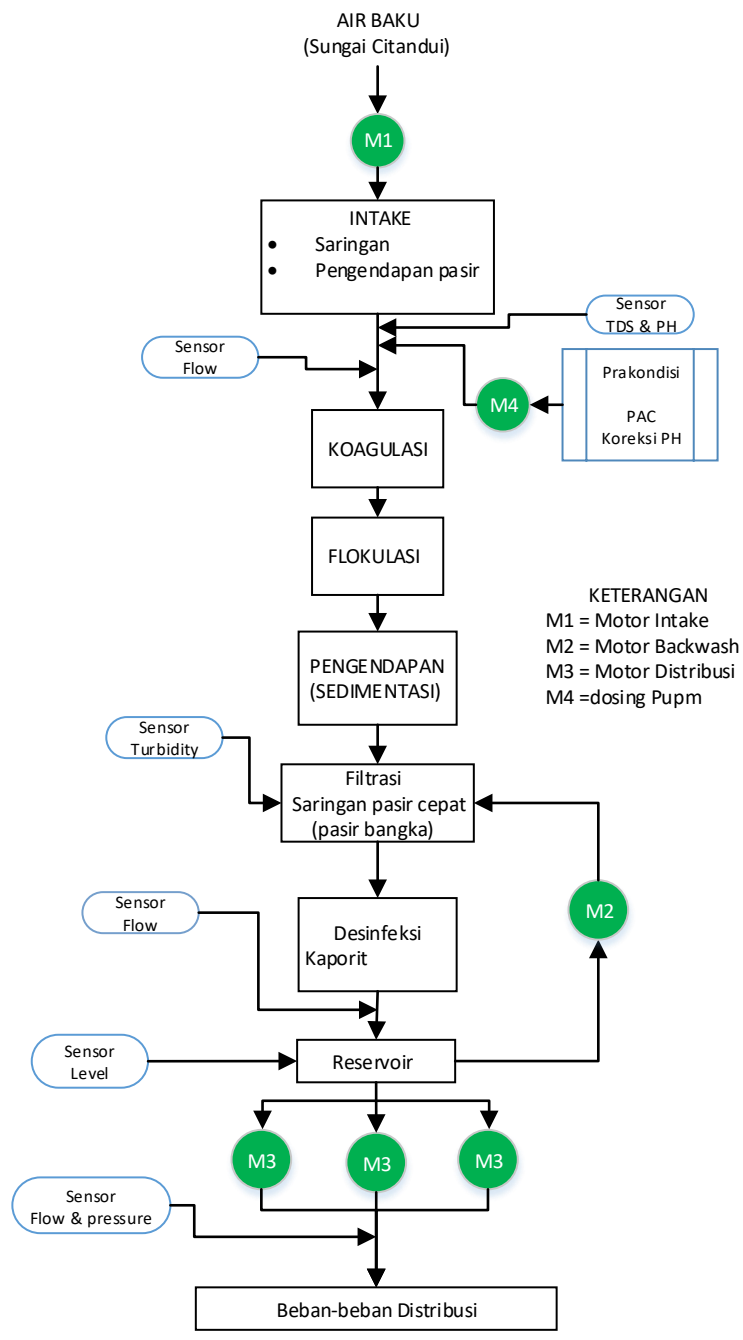

Gbr 4. Arsitektur

\section{B. Perancangan Sistem}

Perancangan sistem menggambarkan keseluruhan sistem yang dibuat yang dituangkan dalam bentuk blok diagram sistem dan sistem komunikasi yang telah dirancang seperti pada Gbr 5 dan Gbr 6. 


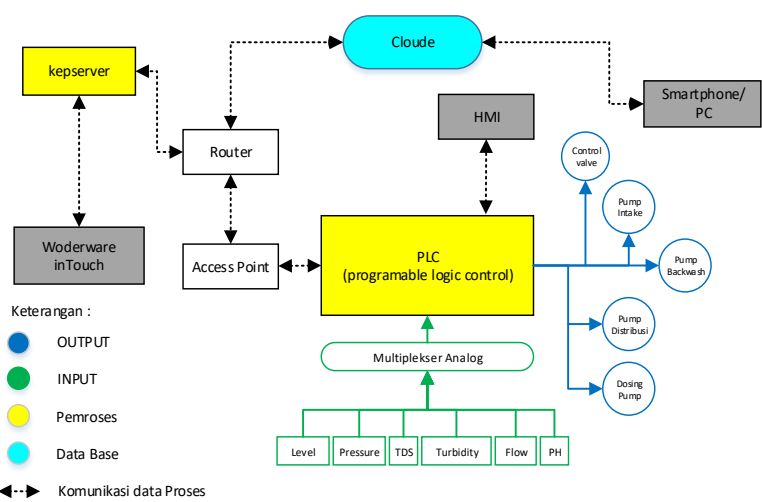

Gbr 5. Blok diagram Sistem

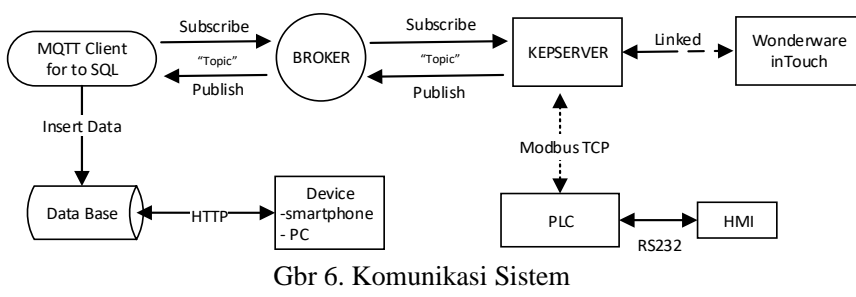

Pada tahap perancangan sistem dilakukan juga pemilihan spesifikasi untuk kebutuhan sistem ini. Pemilihan spesifikasi didasarkan pada kebutuhan yang telah dipertimbangkan di lapangan.

\section{1) Wireless Adapter}

Ada 2 jenis wireless adapter yang digunakan seperti pada Gbr 7. Pada sisi PLC menggunakan TP-LINK WA7001ND sebagai media komunikasi PLC melalui wireless, kedua pada sisi PC menggunakan TP-LINK WN722N. Untuk spesifikasinya dapat dilihat pada Tbl 1.

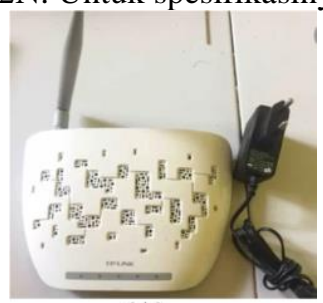

(A)

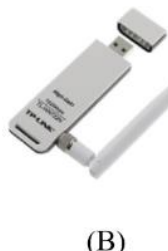

(B)
Gbr 7. Wireless Adapter

(A) TP-LINK TL-WA701ND, (B) TP-LINK TL-WN722N

Tbl 1. Spesifikasi Wireless adapter

\begin{tabular}{llll}
\multicolumn{4}{c}{ Tbl 1. Spesifikasi Wireless adapter } \\
\hline No & Spesifikasi & TL-WN722N & TL-WA701ND \\
\hline 1. & $\begin{array}{l}\text { Power } \\
\text { Suplay }\end{array}$ & $5 \mathrm{~V} / 0.5 \mathrm{~A}$ & $9 \mathrm{~V} / 0.6 \mathrm{~A}$ \\
\hline 2. & Frekuensi & $2.4 \mathrm{Ghz}$ & $2.4 \mathrm{Ghz}$ \\
\hline 3. & Antena & $4 \mathrm{dbi}$ & $5 \mathrm{dbi}$ \\
\hline 4. & Koneksi & USB 2.0 & Ethernet \\
\hline 5. & Mode & Client & Acces Point, \\
& Oprasi & & $\begin{array}{l}\text { Client,WDS,Bridge } \\
\text { with AP. }\end{array}$ \\
\hline
\end{tabular}

\section{Desain Interface}

Perancangan untuk desain interface terbagi menjadi 3 bagian yang masing-masing ditempatkan di tempat berbeda sesuai kegunaannya. Seperti pada Gbr 8.

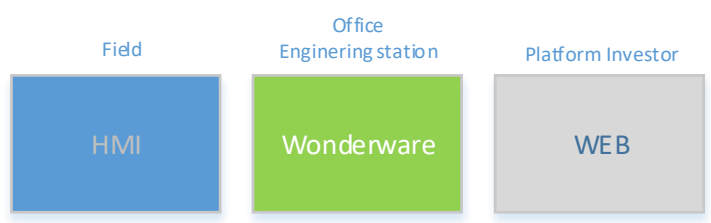

Gbr 8. Blok Region Interface

Perancangan Desain Interface untuk HMI dapat dilihat seperti pada Gbr 9, untuk desain interface pada wonderware seperti pada Gbr 10, dan untuk desain interface pada WEB seperti pada Gbr 11, semuanya menggambarkan fitur yang akan ditampilkan pada masing-masing blok region interface.

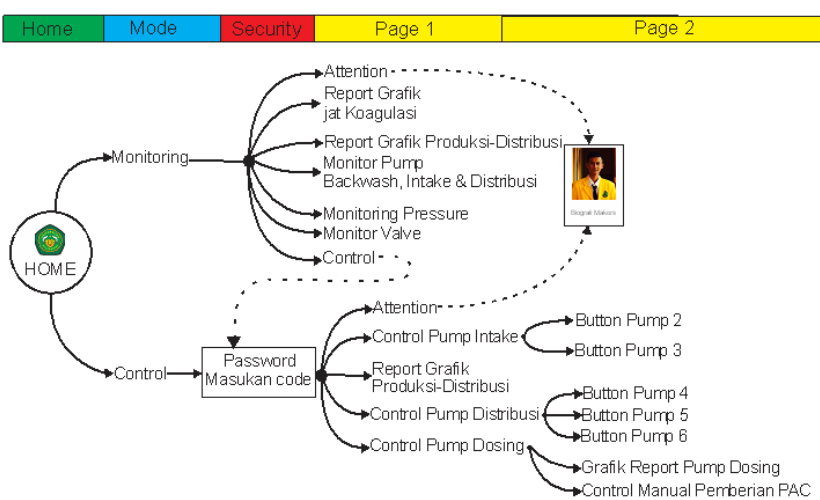

Gbr 9. Desain perancangan interface HMI

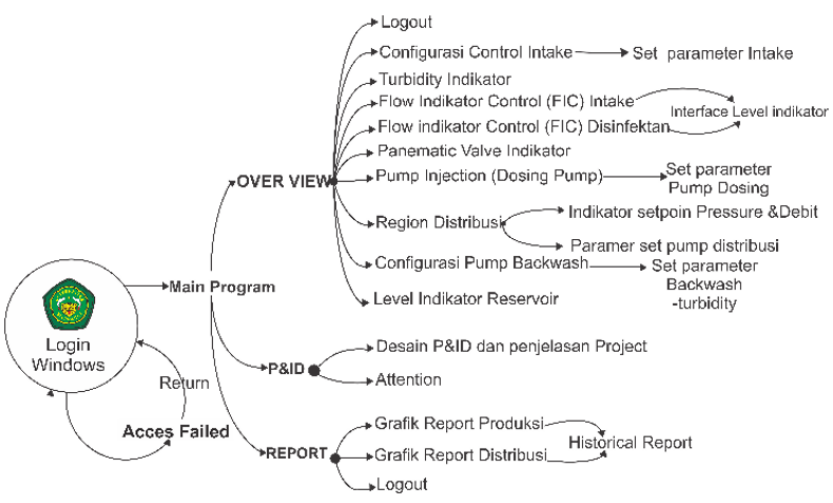

Gbr 10. Desain perancangan interface Wonderware inTouch.

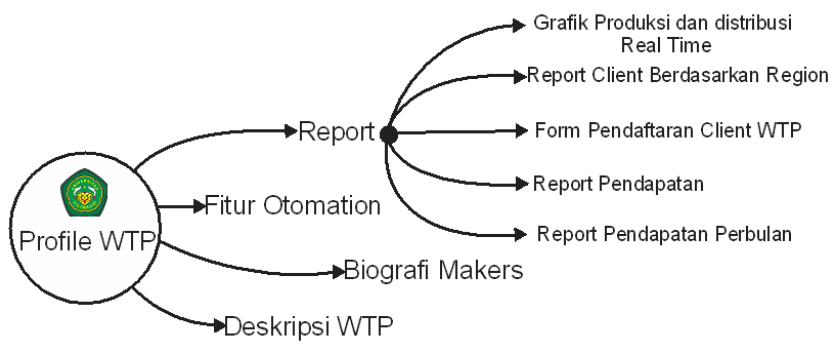

Gbr 11. Desain perancangan interface WEB

\section{Flowchart Sistem}

Flowchart sistem dapat dilihat pada Gbr 12, berisi tentang awal mula dari menjalankan OPC (kepserver) dan modul sistem, menghubungkan model sistem dengan OPC sampai data dapat diakses dari wonderware dan web. 


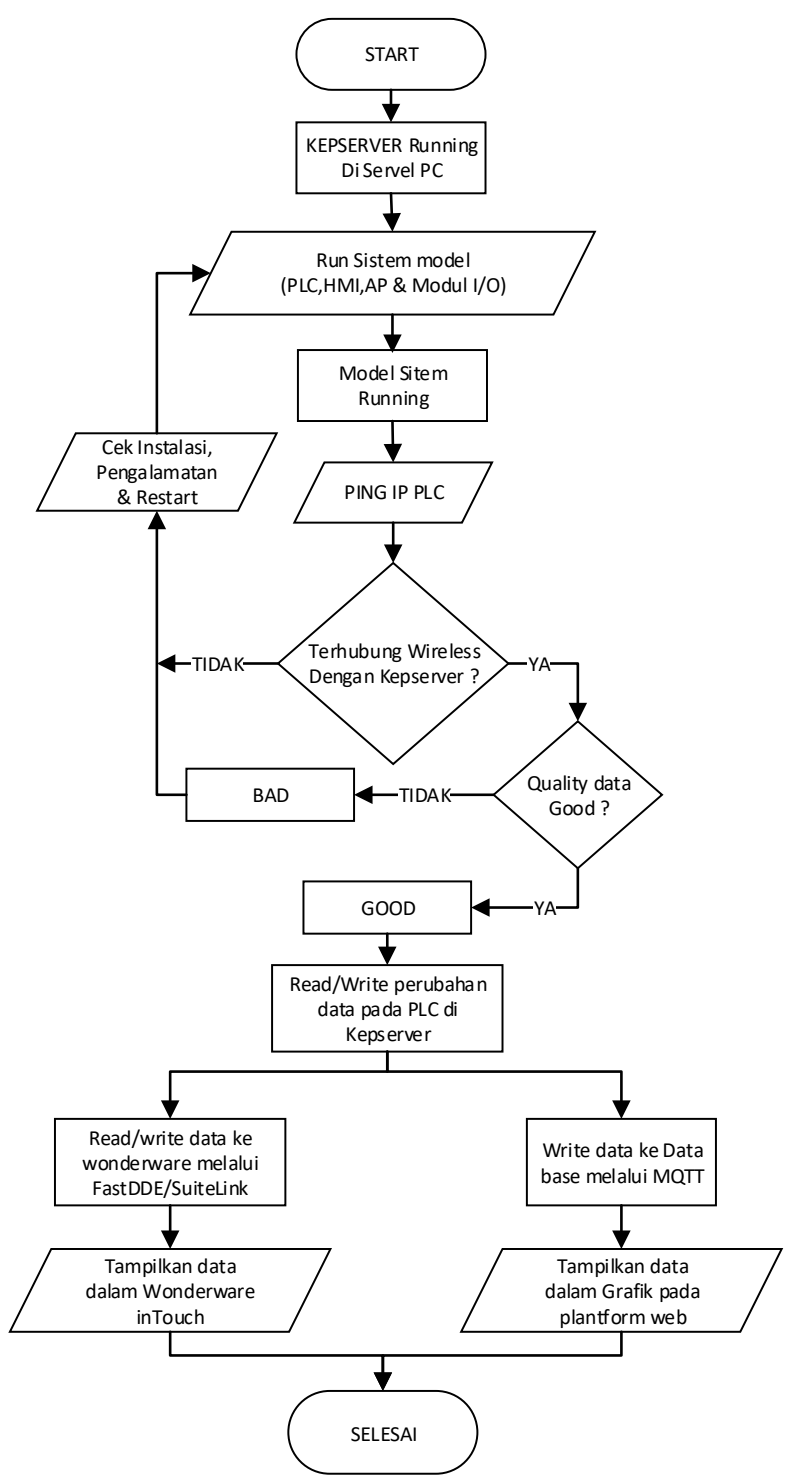

Gbr 12. Flowchart Sistem

\section{HASIL DAN PEMBAHASAN}

\section{A. Pengujian Demultiplexer}

Pada pengujian demultiplexer dilakukan dengan memberikan tegangan ke Modul demultiplexer rentang 1-5 volt dan dibandingkan dengan data ADC tanpa demultiplexer (langsung ke pin analog PLC).

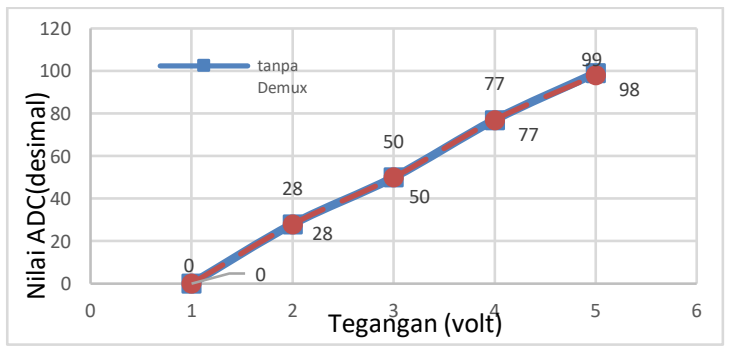

Gbr 13. Pengujian Demultiplexer

Dari hasil pengujian terlihat pada Gbr 13 error terjadi ketika demultiplekser diberi tegangan 5volt, jadi untuk ratarata eror nya adalah:

$$
\% \text { error }=\frac{\Sigma x-\Sigma y}{\Sigma y}=\frac{253-254}{254} x 100 \%=0.39 \%
$$

Dimana : $\mathrm{x}=$ demux

$$
y=\text { tanpa demux }
$$

Jadi untuk presentase error menggunakan demultiplekser analog pada PLC sebesar $0.39 \%$.

\section{B. Pengujian Komunikasi Data}

Pada tahap pengujian ini dilakukan dengan melihat seberapa akurat data yang di request dengan yang diterima dan melihat data apa yang dikirim dengan yang di terima dan berapa waktu yang diperlukan untuk proses transaksi data tersebut.

1) Performance Transfer data wireless

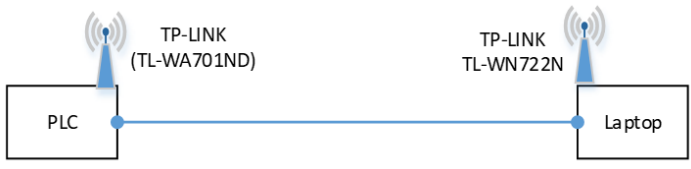

Gbr 14. Teknis pengujian performance transfer data wireless

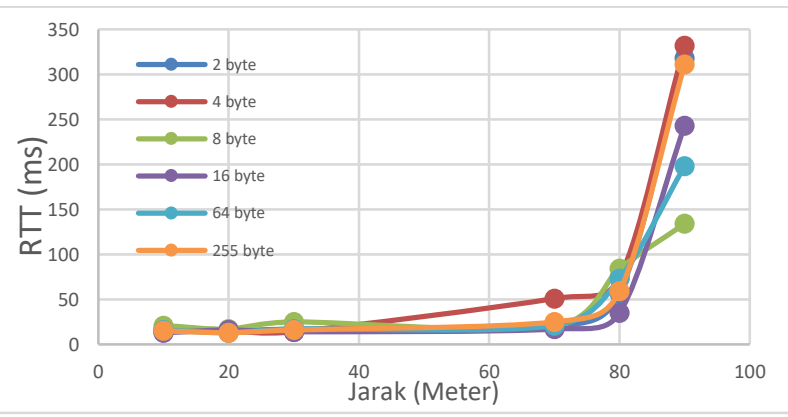

Gbr 15. Pengujian Performance Transfer data wireless

Tbl 2. Rata-rata pengujian performance data wireless

\begin{tabular}{ccc}
\hline Jarak (meter) & RTT $(\mathrm{ms})$ & RTO \\
\hline 10 & 16 & 0 \\
\hline 20 & 14.83 & 0 \\
\hline 30 & 17.16 & 0 \\
\hline 40 & 18.33 & 0 \\
\hline 50 & 14 & 0 \\
\hline 60 & 25.5 & 0 \\
\hline 70 & 25.67 & 0 \\
\hline 80 & 63.67 & 0 \\
\hline 90 & 256 & 2 \\
\hline
\end{tabular}

Untuk teknis pengujian seperti pada Gbr 14 dan pengujian performance transfer data secara wireless seperti pada Gbr 15, didapatkan bahwa nilai RTT akan semakin naik berdasarkan jumlah data. Menurut Tbl.2 rata-rata hasil pengujian pada jarak 90 meter sering terjadi RTO (request time out). Jadi untuk jarak transfer ideal $<80$ meter.

\section{2) Pengiriman Data Ke $O P C$}

Pada pengujian transfer data dari PLC ke OPC yang menggunakan protokol Modbus TCP seperti yang terlihat pada Tbl 3 akurasi mencapai $100 \%$ jumlah data yang di transfer dengan yang diterima itu sama, namun pada saat timepulse pengiriman dipercepat sampai 0.1 detik sekali, ada loss sebanyak 6 data, jadi akurasi ketika 0.1 detik sekali adalah $94 \%$. 
Tbl 3. Pengujian transfer data PLC ke OPC

\begin{tabular}{cccccc}
\hline No & $\begin{array}{c}\text { Time } \\
\text { pulse } \\
\text { (detik) }\end{array}$ & $\begin{array}{c}\text { Uji sampel } \\
\text { pengiriman }\end{array}$ & $\begin{array}{c}\text { Jumlah } \\
\text { data } \\
\text { diterima }\end{array}$ & $\begin{array}{c}\text { Error } \\
\text { rata- } \\
\text { rata } \\
(\%)\end{array}$ & $\begin{array}{c}\text { Defferentian } \\
\text { time } \\
\text { rata-rata } \\
\text { (detik) }\end{array}$ \\
\hline 1 & 3 & $100 \mathrm{x}$ & $100 \mathrm{x}$ & 0 & 0 \\
\hline 2 & 1 & $100 \mathrm{x}$ & $100 \mathrm{x}$ & 0 & 0 \\
\hline 3 & 0.5 & $100 \mathrm{x}$ & $100 \mathrm{x}$ & 0 & 0 \\
\hline 4 & 0.1 & $100 \mathrm{x}$ & $94 \mathrm{x}$ & 0 & 0 \\
\hline
\end{tabular}

3) Pengujian Insert data ke Database

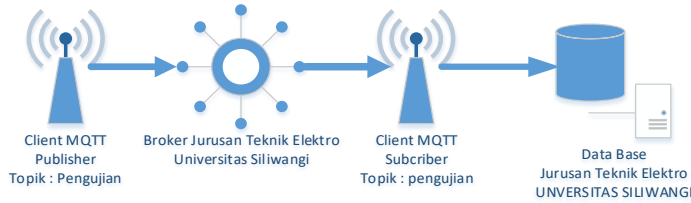

Gbr 16. Teknis pengujian insert data ke database

Teknis pengujian insert database melalui protokol MQTT dapat dilihat seperti Gbr 16 dan untuk hasil yang diperoleh seperti pada Tbl 4, dimana akurasi mencapai 100\% , dalam waktu pengiriman sekitar $0-1,15$ detik.

Tbl 4. Pengujian insert data ke database

\begin{tabular}{cccccc}
\hline No & $\begin{array}{c}\text { Time } \\
\text { pulse } \\
\text { (detik) }\end{array}$ & $\begin{array}{c}\text { Uji } \\
\text { sampel }\end{array}$ & $\begin{array}{c}\text { Jumlah } \\
\text { data } \\
\text { diterima }\end{array}$ & $\begin{array}{c}\text { Data } \\
\text { Error } \\
(\%)\end{array}$ & $\begin{array}{c}\text { Defferentian } \\
\text { time } \\
\text { rata-rata } \\
\text { (detik) }\end{array}$ \\
\hline 1 & 3 & $100 \mathrm{x}$ & $100 \mathrm{x}$ & 0 & -0.87 \\
\hline 2 & 1 & $100 \mathrm{x}$ & $100 \mathrm{x}$ & 0 & 0 \\
\hline 3 & 0.5 & $100 \mathrm{x}$ & $100 \mathrm{x}$ & 0 & -0.23 \\
\hline 4 & 0.1 & $100 \mathrm{x}$ & $100 \mathrm{x}$ & 0 & -1.15 \\
\hline
\end{tabular}

\section{Pengujian Sistem}

Pengujian sistem dilakukan untuk mengetahui kinerja sistem sesuai dengan yang direncanakan atau tidak, seperti pengujian kontrol pump intake, distribusi, backwash, dan alarm untuk emergensi, semua hal itu di ujikan dalam bentuk simulasi.

1) Simulasi dan pengujian indikator kontrol pump intake

Pada pengujian ini dilakukan pengujian penyalaan pump intake secara otomatis pada ketinggian bak reservoir 2 sampai 4.5 meter, pengujian ini dilakukan dengan menurunkan level air pada bak reservoir kemudian menaikanya kembali sampai mencapai ketinggian lebih dari 4.5 meter.

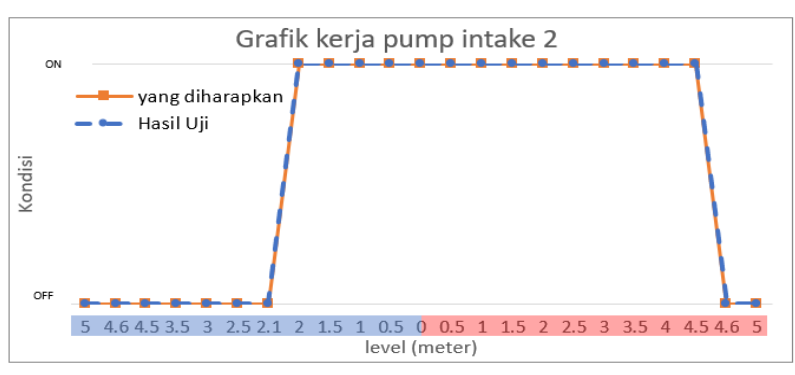

Gbr 17. Grafik kerja pump intake 2 otomatis

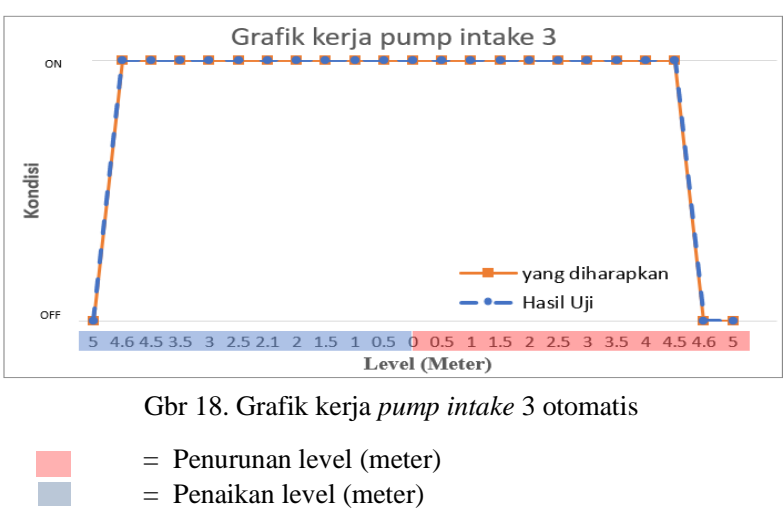

Untuk pengujian simulasi otomatis penyalaan pump 2 pada Gbr 17 dan pump 3 pada Gbr 18 diperoleh sesuai dengan yang diharapkan dimana hasil pengujian sesuai dengan algoritma yang ditanamkan pada PLC.

2) Simulasi dan pengujian kontrol pump distribusi

Pada pengujian simulasi indikator kontrol pump distribusi dilakukan dengan menurunkan nilai pressure dan menaikannya kembali. Untuk set value pengujian otomatis distribusi dapat dilihat pada Gbr.19.

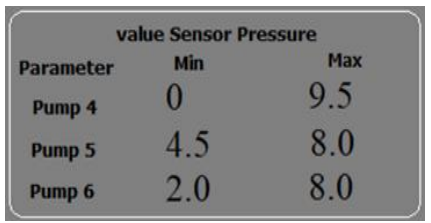

Gbr 19. value sensor pump distribusi otomatis

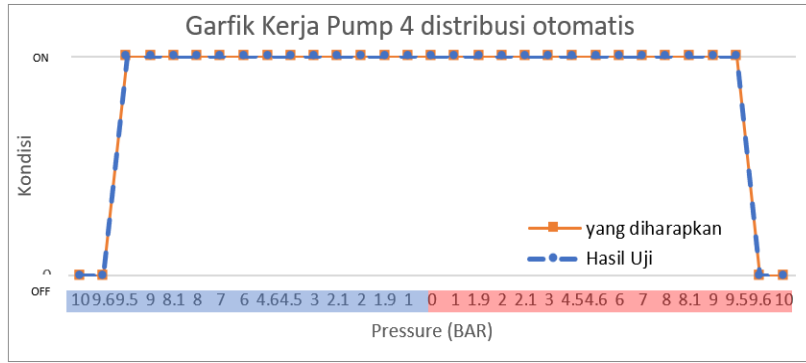

Gbr 20. Gambar kerja pump 4 distribusi otomatis

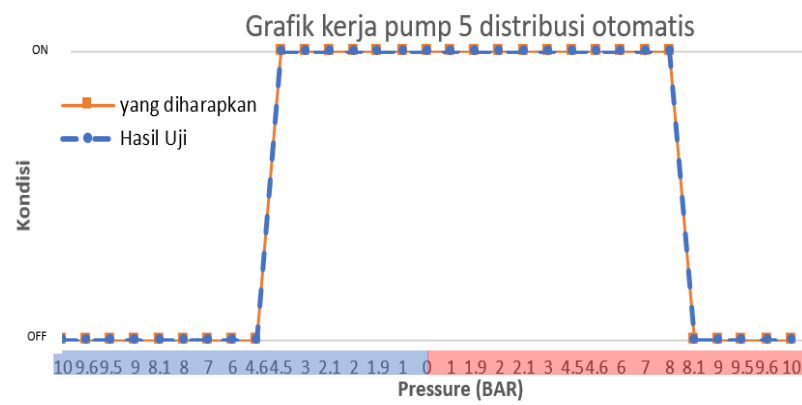

Gbr 21. Gambar kerja pump 5 distribusi otomatis Grafik Kerja Pump 6 distribusi Otomatis

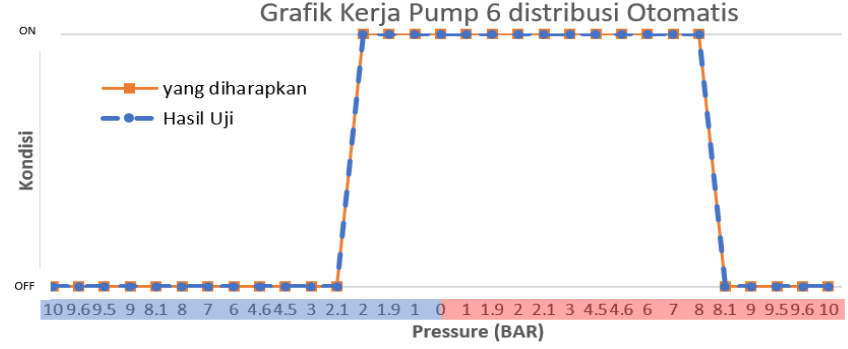

Gbr 22. Gambar kerja pump 6 distribusi otomatis 


\section{Keterangan :}

$$
=\text { Penurunan Pressure (BAR) }
$$$$
=\text { Penaikan Pressure (BAR) }
$$

Untuk pengujian sistem indikator kontrol distribusi sesuai dengan perancangan dimana data out pump 4, pump 5 , pump 6 pada distribusi yang dapat dilihat pada Gbr 20, Gbr 21 , Gbr 22, bekerja sesuai dengan paramerter pressure sudah di tentukan sebelumnya.

\section{3) Simulasi dan pengujian kontrol pump backwash}

Pengujian ini dilakukan dengan menaikan dan menurunkan nilai turbidity dan melihat respon pada sistem backwash bekerja sesuai rancangan atau tidak, untuk sistem backwash terdiri dari selenoid valve 2, solenoid valve 3 , Soledoid valve 4, dan pump 1, yang mempengaruhi kerja kontrol intake ketika backwash dalam posisi running. untuk set value kerja backwash dapat dilihat pada Gbr 23.

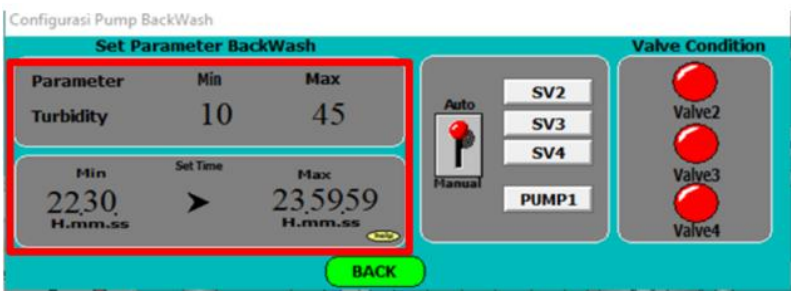

Gbr 23. Konfigurasi set-value turbidity kontrol backwash

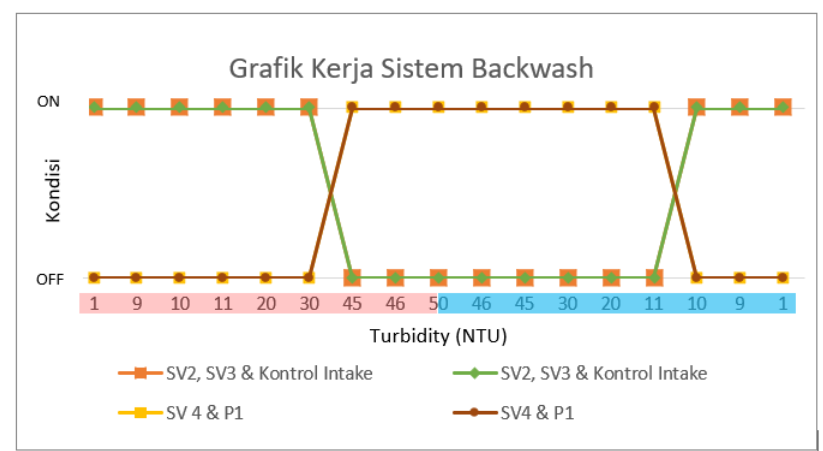

Gbr 24. Konfigurasi set-value turbidity kontrol backwash

Proses backwash akan terjadi apabila nilai turbidity memenuhi set value yang di atur sebelumnya seperti yang terlihat pada Gbr 24. Pump 1 dan Solenoid valve 4 akan aktif ketika kondisi turbidity bernilai 45 NTU. Kemudian untuk SV2, SV3 dan kontrol intake akan mati sampai kondisi turbidity kembali lagi mencapai nilai terendah yaitu 10 NTU. Perubahan dan memenuhi syarat waktu seperti yang ditunjukan oleh Gbr 24.

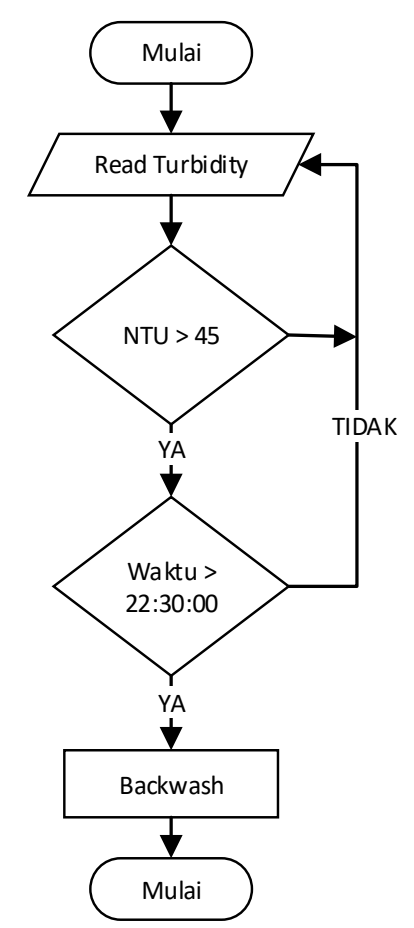

Gbr 25. Flowchart kerja sistem backwash

Proses backwash selain dari parameter turbidity juga dipengaruhi berdasarkan waktu, apabila kondisi waktu belum memenuhi syarat maka backwash tidak dapat dilakukan. Seperti yang dijelaskan pada Gbr 25 .

4) Simulasi dan pengujian Emergensi

Pada pengujian ini dilakukan simulasi emergensi pada sistem water treatment yang sudah dirancang dengan memberi parameter-parameter yang dapat membuat sistem dalam mode emergensi seperti, over current pump 4, pump5, pump6 dan dengan menekan push button emergensi pada plant.

\begin{tabular}{|c|c|c|c|c|c|}
\hline \multirow{2}{*}{ No } & \multirow{2}{*}{$\begin{array}{l}\text { Name } \\
\text { device }\end{array}$} & \multirow{2}{*}{ Kondisi } & \multicolumn{2}{|c|}{ Pop-up Indikator } & \multirow{2}{*}{ Buzzer } \\
\hline & & & HMI & WW & \\
\hline \multirow[b]{2}{*}{1} & \multirow{2}{*}{$\begin{array}{c}\text { Emergency } \\
\text { button }\end{array}$} & $O N$ & Muncul & Muncul & Bunyi \\
\hline & & $O F F$ & $\begin{array}{c}\text { Tidak } \\
\text { Muncul }\end{array}$ & $\begin{array}{c}\text { Tidak } \\
\text { Muncul }\end{array}$ & $\begin{array}{l}\text { Tidak } \\
\text { bunyi }\end{array}$ \\
\hline \multirow[b]{2}{*}{2} & \multirow{2}{*}{$\begin{array}{c}\text { Over } \\
\text { current } \\
\text { Pump } 4\end{array}$} & $O N$ & Muncul & Muncul & Bunyi \\
\hline & & $O F F$ & $\begin{array}{c}\text { Tidak } \\
\text { Muncul }\end{array}$ & $\begin{array}{c}\text { Tidak } \\
\text { Muncul }\end{array}$ & $\begin{array}{l}\text { Tidak } \\
\text { bunyi }\end{array}$ \\
\hline \multirow[b]{2}{*}{3} & \multirow{2}{*}{$\begin{array}{c}\text { Over } \\
\text { current } \\
\text { Pump } 5\end{array}$} & $O N$ & Muncul & Muncul & Bunyi \\
\hline & & $O F F$ & $\begin{array}{c}\text { Tidak } \\
\text { Muncul }\end{array}$ & $\begin{array}{c}\text { Tidak } \\
\text { Muncul }\end{array}$ & $\begin{array}{l}\text { Tidak } \\
\text { bunyi }\end{array}$ \\
\hline \multirow[b]{2}{*}{4} & \multirow{2}{*}{$\begin{array}{c}\text { Over } \\
\text { current } \\
\text { Pump } 6\end{array}$} & $O N$ & Muncul & Muncul & Bunyi \\
\hline & & $O F F$ & $\begin{array}{c}\text { Tidak } \\
\text { Muncul }\end{array}$ & $\begin{array}{c}\text { Tidak } \\
\text { Muncul }\end{array}$ & $\begin{array}{l}\text { Tidak } \\
\text { bunyi }\end{array}$ \\
\hline
\end{tabular}

Hasil pengujian sistem emergensi yang dapat dilihat pada Tbl 5. Pengujian sesuai dengan perencanan dimana semua kondisi emenrgensi dapat memberikan notofikasi pada HMI,WW, dan buzzer yang berbunyi di plant.

5) Pengujian akurasi data sistem

Pada pengujian tahap ini, dilakukan pengiriman data dari PLC ke OPC kemudian ke database berdasarkan 110 sample yang dilakukan, pada setiap tahap data disimpan dan dibandingkan untuk mengetahui keakurasian,dan lama 
waktu pengirimannya, untuk teknis pengujian seperti pada Gbr 26.

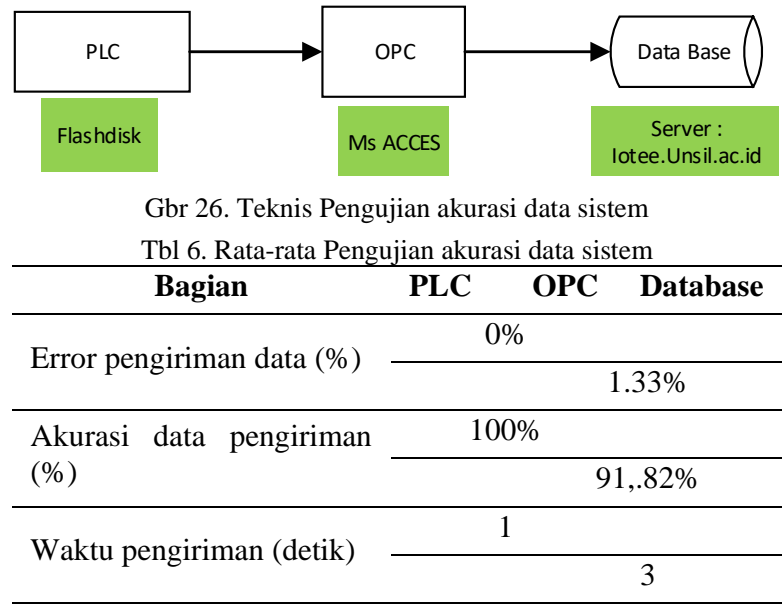

Berdasarkan hasil pengujian yang dilakukan menurut 110 sample yang diberikan seperti pada Tbl 6, diperoleh ratarata error pengujian yang ditunjukan seperti pada Tbl, untuk ke akurasian pengiriman data sensor sampai ke database 91.82 - $100 \%$ dengan waktu pengiriman 4 detik yang mana 1 detik dari pengiriman PLC ke OPC menggunakan protokol Modbus TCP dan 3 detik dari OPC ke database menggunakan protokol MQTT.

\section{KESIMPULAN}

Berdasarkan hasil dari penelitian ini, maka dapat disimpulkan bahwa model sistem otomatis water treatment plant dapat dibuat dalam model otomatisnya dalam menangani hal scheduling penyalaan pump intake berdasarkan kontrol level pada bak reservoir, scheduling penyalaan pump distribusi berdasarkan kontrol pressure pada pipa distribusi, scheduling penyalaan backwash berdasarkan waktu dan kontrol turbidity pada bak filtrasi, dan sistem report yang terakuisi.

Model sistem ini dapat bekerja dan mengirimkan data tanpa terjadi RTO < 80 meter dengan keakurasian data pengiriman dari PLC sampai ke database sekitar 91,82 $100 \%$ dengan lama waktu pengiriman rata-rata selama 4 detik dimana 1 detik dari PLC ke OPC menggunakan protokol modbusTCP dan 3 detik dari OPC ke database menggunakan protokol MQTT.

\section{REFERENSI}

[1] N. N. Naim, I. Taufiqurrahman, and U. Siliwangi, "SISTEM MONITORING PENGGUNAAN DEBIT AIR KONSUMEN DI PERUSAHAAN DAERAH AIR MINUM," vol. 02, no. 01, pp. 31-39, 2020.

[2] M. G. Hudedmani, R. M. Umayal, S. K. Kabberalli, and R. Hittalamani, "Programmable Logic Controller (PLC) in Automation," Adv. J. Grad. Res., vol. 2, no. 1, pp. 37-45, 2017.

[3] N. Hiron and A. Andang, "Wireless communication with batching method based on Xbee-PRO S2B module for sensing of wind speed," Proceeding 2016 2nd Int. Conf. Sci. Inf. Technol. ICSITech 2016 Inf. Sci. Green Soc. Environ., pp. 250-253, 2017.

[4] F. Ramadhan, L. Siami, and W. Winarni,
"Optimalisasi Instalasi Pengolahan Air Minum Solear, PDAM Tirta Kerta Raharja -Kabupaten Tangerang," Semin. Nas. Pembang. Wil. dan Kota Berkelanjutan, vol. 1, no. 1, pp. 132-141, 2019.

[5] D. Cpl-, "CP series CP1L CPU Unit D -D / CP1LEL D -D High Performing Programmable Controller with Embedded Ethernet."

[6] S. N. Edusainstek et al., "DESAIN DAN SIMULASI SISTEM HMI ( Human Machine Interface ) 2 . 1 Teknologi Sistem Konveyor Sistem konveyor adalah peralatan transportasi atau pemindah yang berfungsi untuk mengangkut dan memindahkan bahan-bahan industri . Konveyor biasanya mengangkut dan ," pp. 253-262, 2018.

"KEPServerEX Connectivity Platform | OPC Server | Kepware," PTC Inc, 2020. [Online]. Available: https://www.kepware.com/en-

us/products/kepserverex/. [Accessed: 15-Feb-2020].

[8] R. Hartono and A. Purnomo, "Wireless Network 802.11," D3 Ti Fmipa Uns, vol. 1, no. 1, pp. 1-23, 2011.

[9] R. Hidayat, "Analisis Pemanfaatan Multiplexer Analog 74HC4051 pada Mikrokontroller ATMega16," Isu Teknol., vol. 10, no. 2, 2015.

\section{BIOGRAFI PENULIS}

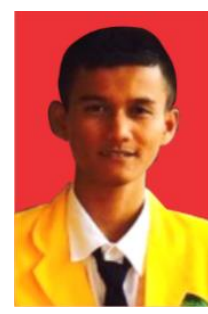

Rendi Priyatna, lahir di Ciamis, 06 April 1998, kuliah di Teknik Elektro Universitas Siliwangi mengambil konsentrasi Sistem Kendali dan untuk penelitian saya mengambil Sistem Otomasi menggunakan PLC berbasis wireless.

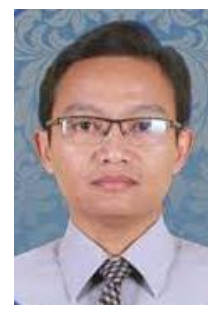

Firmansyah M.S.N., Lahir di xxxx. Bekerja sebagai tenaga pengajar di Program Studi Informatika Universitas Siliwangi dengan bidang konsentrasi xxxx.

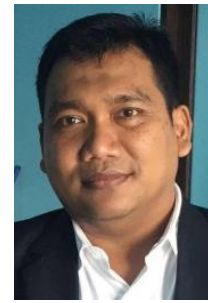

Asep Andang., Lahir di xxxx, 23 Agustus 1976. Bekerja sebagai tenaga pengajar di Program Studi Teknik Elektro Universitas Siliwangi dengan bidang konsentrasi Sistem Kendali. 